\title{
Forum
}

\section{Resolving the Human Remains Crisis in British Archaeology}

\author{
Mike Parker Pearson,* Tim Schadla-Hall ${ }^{\dagger}$ and Gabe Moshenska ${ }^{\dagger}$
}

\section{Introduction}

Human remains are a fundamental part of the archaeological record, offering unique insights into the lives of individuals and populations in the past. Like many archaeological materials human remains require distinctive and specialised methods of recovery, analysis and interpretation, while technological innovations and the accumulation of expertise have enabled archaeologists to extract ever greater amounts of information from assemblages of skeletal material. Alongside analyses of new finds, these advances have consistently thrown new light on existing collections of human remains in museums, universities and other institutions. Given the powerful emotional, social and religious meanings attached to the dead body, it is perhaps unsurprising that human remains pose a distinctive set of ethical questions for archaeologists.

With the rise of indigenous rights movements and the emergence of post-colonial nations the acquisition and ownership of human remains became a divisive and politically loaded issue. It became increasingly clear that many human remains in museum collections around the world represented the traces of colonial exploitation and discredited pseudo-scientific theories of race. In the light of these debates and chang-

\footnotetext{
* University of Sheffield

+ UCL Institute of Archaeology
}

ing attitudes, some human remains were returned or repatriated to their communities of origin, a process which continues to this day. Recently a new set of challenges to the study of human remains has emerged from a rather unexpected direction: the British government revised its interpretation of nineteenth-century burial legislation in a way that would drastically curtail the ability of archaeologists to study human remains of any age excavated in England and Wales. This paper examines these extraordinary events and the legal, political and ethical questions that they raise.

The Emergence of Compulsory Reburial

In April 2008 the British government announced that, henceforth, all human remains archaeologically excavated in England and Wales should be reburied after a two-year period of scientific analysis. Not only would internationally important prehistoric remains have to be returned to the ground, removing them from public view, but also there would no longer be any possibility of long-term scientific investigation as new techniques and methods emerged and developed in the future. Thus, while faunal remains, potsherds, artefacts and environmental samples could be analysed and re-analysed in future years, human remains were to be effectively removed from the curation process. Archaeologists and other scientists were also concerned that this might be the first step towards a policy of reburying all 
human remains held in museum collections in England and Wales including prehistoric, Roman, Saxon, Viking and Medieval as well as more recent remains.

From some perspectives, it might have seemed that the UK was following the welltrod path of post-colonial nations in returning the ancestral remains of oppressed indigenous minorities for reburial, but, in a number of respects, the situation in Britain is very different (Sayer 2009, 2010; Moshenska 2009). The Ministry of Justice stated that they intended for this ruling to remain in place only temporarily until the law could be amended, perhaps within the next two years. They also pointed out that reburial dates could be extended, subject to permission, so that scientific analysis might continue to be carried out.

The law in question was the Burial Act 1857 , one of a series of largely out-dated burial acts passed during the Victorian period to protect the Victorian public from exposure to recent corpses, grave-robbing and clearance of recent graves in the over-crowded cemeteries and graveyards of the rapidly growing towns and cities of England and Wales. Section 25 of the Act states:

Except in the cases where a body is removed from one consecrated place of burial to another by faculty granted by the ordinary for that purpose, it shall not be lawful to remove any body, or the remains of any body, which may have been interred in any place of burial, without licence under the hand of one of Her Majesty's Principal Secretaries of State, and with such precautions as such Secretary of State may prescribe as the condition of such licence.

By the beginning of the twenty-first century many archaeologists were accustomed to applying for licences from the Home Office to excavate human remains of all periods. Application forms required the nomination of an osteological expert responsible for analysing the remains as well as the identification of a place of eventual deposition, whether a museum or collection for curation, or a place of reburial. Standard conditions, regardless of the antiquity of the remains, included the need to consult a local public health official prior to excavation (entirely unnecessary for archaeological remains over 100 years old) and to screen the excavations from public view so as not to cause offence. In contrast to this anachronistic requirement, most visitors to archaeological sites are extremely keen to see human remains, and surveys of museum visitors have consistently shown an overwhelming majority in favour of their public display. But, despite these occasionally inappropriate conditions, this system worked. Human remains were curated in museums, or sometimes reburied if an ethnic or religious group with close and demonstrable connections to the deceased was identified, and requested such action.

This situation changed in 2007 when the Home Office handed over responsibility for burial legislation to the newly formed Ministry of Justice (MoJ). Lawyers acting for the MoJ decided that the 1857 Act did not in fact give the government the powers to grant licences for the excavation of human remains, and thus it was neither possible nor necessary to issue licences where the remains were not buried in extant burial grounds. They initially tried to apply another act, the Disused Burial Grounds (Amendment) Act 1981, to archaeology, but eventually they advised that archaeologists were not required to obtain exhumation licences for any remains regardless of their date of interment, except in the case of extant burial grounds.

From this state of enlightenment in early 2008, the MoJ changed its view again and, without any published explanation or discussion of its reasons, stated that all human remains would have to be reburied after a two-year period of scientific analysis. The new licences no longer included the option 
of curation in a museum. It is worth noting that the relevant section of the Act thus interpreted makes no reference to reburial, being entirely concerned with the removal of remains. Nearly three years later a government minister's letter (Jonathan Djanogly replying to the Solicitor General, Edward Garnier on 10 February 2011) stated that this was because the 1857 Act contained no express powers to curate remains. This again failed to address the question of why reburial was the only option when this too was not mentioned in the act.

Other than the minister's letter to the Solicitor General, there has never been a published explanation of why the MoJ's legal advice took the form that it did. A possible explanation is that one or more civil servants or their legal advisors held fundamentalist Christian beliefs about the resurrection of the body at the day of judgement; individuals holding such beliefs would be likely to believe that remains from Christian burials should be re-interred as a matter of religious necessity. Fundamental Christian belief may further expect that all pre-Christian and non-Christian remains should be reburied. Representatives of the MoJ have never provided a public statement to clarify their reasoning behind the blanket requirement for reburial. Instead, in 2008 and 2009 the MoJ issued two brief statements recognizing that the legislation needed amendment, and that it would be possible to apply for extensions beyond the two-year period prior to reburial when justified by circumstances.

\section{The Change in MoJ Policy}

By 2010 a number of archaeologists were becoming increasingly concerned that the MoJ had no intention of changing its requirement that all human remains should be reburied regardless of their long-term value for scientific knowledge and public benefit. Officials from the MoJ had been consulting with English Heritage during the previous two years but had failed to communicate the results of these deliberations. By Octo- ber 2010 it appeared that discussions had reached stalemate with no clear outcome other than to maintain the status quo as established in 2008. It was at this point that three archaeologists decided to act.

The issues of reburial and screening of skeletons from public view were first brought to public attention with the publication of a short feature in the December 2010 issue of British Archaeology (published on 8 October) by Mike Pitts, the journal's editor, and Dr Duncan Sayer, lecturer in archaeology at the University of Central Lancashire. The MoJ did not formally respond, but its comments to the media suggested it believed archaeologists were making a fuss about nothing.

Duncan Sayer also wrote to the Science and Technology Committee of the House of Commons at Westminster to ask them to look into the process of licensing with particular reference to (1) reburial causing the potential loss of scientific information, and (2) the disadvantages and lack of necessity of screening archaeological excavations from the public. On 14 October he appeared on BBC Radio 4's Material World together with Mike Pitts, to explain the problems and inadequacies of the MoJ's stance. The MoJ declined to provide a spokesperson on the show. The responses to the broadcast included an article in the Observer newspaper, a call for a review of the guidance from the Council for British Archaeology (CBA), and an enquiry from the Law Commission, a statutory body whose function is to review the law and make recommendations for legal reform.

On 14 October 2010 Andrew Millar MP, chair of the Science and Technology Committee, wrote to Kenneth Clarke, Lord Chancellor and Secretary of State for Justice, to express concern over the working of the licensing system. Kenneth Clarke replied on 1 November 2010 stating that, as far as he understood, the archaeological profession had no problem with the existing situation, and that his ministry had 'not received any formal representations against the licensing 
scheme introduced in 2008'. On 11 January, Lord Renfrew received a written answer to the following question in the House of Lords:

To ask Her Majesty's Government whether they will amend the Burial Act 1857 to ensure that significant prehistorical or ancient human remains can lawfully be conserved and curated in perpetuity in appropriate museums or designated institutions for the purpose of scientific study and research.

The written answer from Lord McNally, Minister of State for Justice, gave little away:

We are currently considering whether it may be possible to take forward changes to burial legislation generally, including the Burial Act 1857 which regulates the exhumation of human remains. In the mean time, we continue to apply the present exhumation licensing system in a way which recognises, as far as possible, the legitimate interests of archaeologists, museum professionals, and the general public.

Despite this vague reply, civil servants at the MoJ were now aware that there was a mounting campaign at government level. Robert Clifford, the senior civil servant responsible for the MoJ's policy, hastily convened a meeting with a panel of representatives of different archaeological organizations including English Heritage, the Institute for Archaeologists and the CBA. Such panel meetings were supposed to be part of a regular consultation process but this was the first time that the panel had met since the MoJ's policy change over two years before.

The Ministry of Justice panel met on 18 January but were advised by Robert Clifford not to reveal the nature or results of their discussions for a further month. Although the MoJ did not feel that changes to the current burial laws were feasible, they explained that they hoped to work towards a more flexible approach in which reburial of remains would not normally be a requirement. That same day the Solicitor General Edward Garnier QC MP wrote to Jonathan Djanogly to ask about the legal basis for the MoJ's current policy of reburial. On 10 February he received a reply stating that the legislation could allow a wider range of options than merely reburial.

On 2 February 2011 a group of 40 professors of archaeology and related sciences published an open letter to Kenneth Clarke in the Guardian (published simultaneously in British Archaeology) to explain that the 2008 arrangements for compulsory reburial had caused deep and widespread concern and that the MoJ should return to a licensing system that allowed for the retention, study, curation and display of excavated remains as appropriate. Clarke's minister responsible for burial law, Jonathan Djanogly initially replied with a letter to the Guardian, stating that the professors were 'wide of the mark'.

However, it turned out that their letter had indeed hit the mark. Djanogly and his civil servants replied to the professors on 10 February in much greater detail, apologising for the fact that Kenneth Clarke's letter gave the impression that the MoJ were not aware of archaeologists' concerns over the burial legislation, and recognising that the situation was clearly unsatisfactory. He concluded that the provisions of the Act could be applied more flexibly in future: there was little chance, he explained, that the burial legislation would be reformed in the short or medium term but he was confident that a more satisfactory way forward could be found to allow the retention of human remains in appropriate circumstances.

Later in the year, MoJ officials began granting licences for retention of human remains in museums. They also re-opened negotiations with representatives of English Heritage and the Institute for Archaeologists to develop a new policy for human remains which included a new form of application in 
which museum curation could be considered alongside reburial.

There is no likelihood that the current government will support the introduction of new legislation on this matter, even though it is clearly needed. There is also no legal certainty that the 1857 Act has any relevance whatsoever for human remains not found in extant burial grounds. There is also no certainty under the new system that MoJ officials will always make decisions that safeguard the archaeological resource for longterm study. In Djanogly's letter to Garnier, he stated that 'it falls to us to balance differing interests, and to reach a reasonable, balanced and proportionate decision.'

\section{Discussion}

The events described in this article highlight a number of problems that should give all archaeologists cause for concern. The weaknesses and contradictions in the legal frameworks that govern archaeology are shocking in many respects, and cannot remain unresolved; archaeologists are pulled hither and thither by property law and planning law, while human remains exist in a peculiar (but ethically and morally appropriate) legal limbo in that they cannot technically be owned. The substance of the challenges to archaeological control of human remains highlights a weakness in the most common statements on archaeological ethics, which tend to deal in woolly abstractions of 'respect' for a range of viewpoints, and thereby elide the legal intricacies and political intrigues where real power resides outside the seminar room. A related area of concern is the weakness and lack of coordination of the archaeological community in lobbying, evident both in the delays before action was taken and in the dismissive responses with which the protests were met - at least initially. The role of a few individuals in maintaining pressure on this matter is thus both more necessary and more praiseworthy.

A final, more general matter of concern is that faint echoes may be heard of a pernicious religiosity that seeks to curtail the practice of science: a phenomenon more common in the United States. The possibility that any individual's interpretation of Christian doctrine could have such a damaging effect on archaeological scholarship is alarming, particularly as it coincides with the efforts of a number of new religious movements to similarly restrict the study of human remains in Britain through legal challenges and lobbying. The impact of the potential loss of osteological reference collections cannot be compared to the retardation of medical research brought about by religious groups lobbying against stem cell research, but the principles are the same. For now, at least, this threat appears to be minor and manageable, but vigilance is necessary to defend the academic freedoms we take for granted, such as the ability to curate human remains, from religious zealots seeking to impose their values on others.

We need to engender a spirit of assertiveness and identity within the archaeological community so that, in the face of challenges such as this, we can present a confident and coherent public face. When it comes to the care and stewardship of the historic environment, archaeologists are not one interest group among many: unfashionable as it may be to say so, we are the experts. Those of us who want a strong archaeology tomorrow must fight for it today in the face of defective legislation, religious machinations and official indifference.

\section{References}

Moshenska, G 2009 'The reburial issue in Britain'. Antiquity 83: 815-20.

Sayer, D 2009 'Is there a crisis facing British burial archaeology?' Antiquity 83: 199205.

Sayer, D 2010 Ethics and Burial Archaeology. London: Duckworth.

Sayer, D and Pitts, M 2010 'The human remains crisis'. British Archaeology 115: 34-35. 